\title{
Programmed cell death in the nucellus of Tillandsia (Brome- liaceae)
}

\author{
Brighigna $^{2, *}$ Luigi, Alessio Papini ${ }^{2}$, Eva Milocani $^{2}$ and Jose L. Vesprini ${ }^{1}$ \\ ${ }^{1}$ CONICET. Facultad de Ciencias Agrarias UNR cc14 S2125ZAA, Zavalla, Argentina \\ 2 Dipartimento di Biologia Vegetale, Università degli Studi di Firenze, via Micheli 3, 50121 Firenze, Italia \\ In memory of Professor Eleonora Francini-Corti.
}

The authors thank Ente Cassa di Risparmio di Firenze for support under grant n 2002.1076 to J.L.V. Teresa Ghiglione and Gabriela Venturi for English corrections.

\begin{abstract}
We report the ultrastructural aspects and histochemical assay regarding the degenerating nucellar cells of Tillandsia during early female gametophyte development. Nucellar cells degeneration was observed to start during the somatogenesis of the gametophyte. Ultrastructural features of degenerating process and TUNEL assay indicated that the nucellar cells death mechanism is genetically controlled. Mitochondria and cytoplasmic vesicles persisted until cell degeneration was completed. This feature represens a peculiar aspect of the PCD mechanism in this specific case.
\end{abstract}

Key words: nucellus; PCD; Tillandsia; TUNEL; ultrastructure.

\section{INTRODUCTION}

The ovule, a salient anatomic feature of spermatophytes, is traditionally described as a megasporangium or nucellus surrounded and protected by one or two integuments (HERR 1995). The nucellus is that vegetative tissue within the ovule in which a typically diploid vegetative megaspore mother cell undergoes meiosis, giving rise to four megaspores containing half of the chromosome complement of the vegetative plant. The female gametophyte develops from the "functional' megaspore which undergoes three rounds of mitosis, subsequent nuclear migrations, nuclear fusion and cellularization.

In the Gymnosperms, where the reproductive cycle is usually longer than that of the Angiosperms, the female gametophyte concludes its development within the nucellus only after the previous events of fertilization start. In the Angiosperms, the results of the double fecundation accompany the reduction to few cells of the female gametophyte, or embryo sac (FrIEDMAN 1994), which is already developed before the

\footnotetext{
*Corresponding author: e-mail: luibrig@unifi.it
}

sexual events. Ultrastructural analyses have shown that in wheat (Triticum) the nucellus suffers a degenerative process, which starts soon after fertilization (Norstog 1974; Morrison, O’BrIEN and KuO 1978).

Six categories of cells that undergo programmed cell death (PCD) are known in plants, but the mechanism of (PCD) has been studied only in four categories (KRISHNAMURTHY et al. 2000). The most exhaustively studied category is that which includes those cells subjected to various abiotic and biotic stresses that cause a hypersensitive response (KRISHNAMURTHY et al. 2000). Depending upon the intensity of the stress and the proximity of cells to the stressing agent, cells can undergo PCD or necrosis. VAN Doorn and WoLTERING (2005) proposed three different categories of plant PCD: apoptotic, autophagic and neither apoptotic nor autophagic. Most probably, the nucellar cells adjacent to the female gametophyte in expansion belong to the category of the hypersensitive response.

In this work on the mature ovule of some Tillandsia species, we present the results of an ultrastructural and histochemical (TUNEL assay) research. Our results show the precocious degeneration, before fertilization, of the nucellar cells around the female gametophyte. Our preliminary 
hypothesis was that the development of the embryo sac might cause some stress to the adjacent nucellar cells which die. The aim of the present research was to understand if the nucellar cells degeneration is due to PCD or necrosis.

\section{MATERIALS AND METHODS}

Anatomy and ultrastructure - Plants of Tillandsia meridionalis Baker and T. ixioides Gris. were collected in the experimental station of Las Gamas (Santa Fe, Argentina). Flowers were dissected at various developmental stages before and after anthesis. Pieces of ovary were prefixed overnight in $1.25 \%$ glutaraldehyde, in cold $\left(5^{\circ} \mathrm{C}\right) 0.05 \mathrm{M}$ phosphate buffer ( $\mathrm{pH}$ 6.8), then posfixed in osmium tetroxide at $2 \%$ for $2 \mathrm{hr}$ in the same buffer. After dehydration in an ethanol series the samples were embedded in Spurr's epoxy resin (SPURR 1969). Semithin sections (1-5 $\mu)$ obtained using glass knives, were contrasted with Toluidine Blue $0,1 \%$, then observed with the optical microscope. Transverse sections of approximately $800 \mathrm{~nm}$ thick were cut with a diamond knife, stained with uranyl acetate (GibBons and Grimstone 1960) and lead citrate (REYNOLDS 1963), then examined in a Philips 200 transmission electron microscope at $80 \mathrm{Kv}$.

In situ detection of DNA fragmentation - A subset of the material fixed for the electron microscopy was embedded in Technovit 7100 resin (Kulzer, Germany). Semithin sections $(5-8 \mu)$ were obtained with glass knives with a Reichert Om U3 ultramicrotome. In-situ Cell-Death-Detection Kit (Roche Diagnostics, Mannheim, Germany) was applied to the sections (TUNEL assay). The procedure was: the sections were digested for $15 \mathrm{~min}$ at RT with proteinase $\mathrm{K}\left(10 \mathrm{mg} \mathrm{ml}^{-1}\right)$, briefly rinsed twice with a phosphate buffer $0.1 \mathrm{M}$ at $\mathrm{pH}$ 6.8 , then incubated in a humidified atmosphere with labeling mix (10 U TdT, $0.5 \mathrm{nM}$ dig-11dUTP, in $50 \mu \mathrm{l}$ of TdT buffer per slide) for $1 \mathrm{hr}$ at $37^{\circ} \mathrm{C}$ in the dark. The reaction was terminated by rinsing the slides three times with the phosphate buffer. Samples were observed in a drop of buffer under fluorescent microscope Leika DM RB Fluo in the range of 515-565 nm (green). For the analysis at light microscopy the samples were added to $50 \mu \mathrm{l}$ of Converter-POD, incubated in a humidified chamber for $30 \mathrm{~min}$ al $37^{\circ} \mathrm{C}$, rinsed three times in the phosphate buffer, added with $100 \mu \mathrm{l}$ DAB Substrate, and again incubated for $10 \mathrm{~min}$ at $20^{\circ} \mathrm{C}$. Finally rinsed three times with the phosphate buffer.

\section{RESULTS}

Ultrastructural analysis - The developing ovule of Tillandsia reaches its final dimension when meiosis has already occurred. Most probably the initial growth of the functional megaspore is possible due to the space left by the supernumerary megaspores degeneration.

Signals of nucellar cells degeneration were soon observed around the female gametophyte in concert with its expansion. The process of cell degeneration took place with the following modifications. The first significant observable anomaly in comparison with the normal nucellar cells - was the space subsequent to the detachment of plasmalemma from cell walls (Fig. 1). This space was filled with a lot of small cytosolic droplets probably released out of the cell membrane. At the same time the whole protoplast increased in electrondensity. The cytoplasm was rich in ribosomes and in rough endoplasmic reticulum; there were small vacuoles containing abundant electrondense material (Fig 2-4a); strands of markedly dilated smooth endoplasmic reticulum occurred. Also the cell shape changed (Fig. 2).

More advanced degenerating cells assumed a flat shape. Their nucleus showed an increase in electrondensity due to the aggregation and condensation of chromatin. The interval between the two nuclear membranes (perinuclear space) was dilated, thus forming enlargements in some tracts (Fig. 3). Also endoplasmic reticulum elements, particularly those which were connected with the nuclear envelope were noteworthy dilated (Fig. 4). Consequently the cytoplasm was subdivided into bodies of different shapes and sizes (Fig. 4). These bodies appeared uniformly amorphous and electrondense. Little vesicles were gathered into the modified cytoplasm (Fig. 4). Mitochondria persisted, although without cristae. Plastids were no longer found.

Subsequent aspects of the degenerative process consisted in a further increase in electrondensity of the protoplast which appeared sulcated by long profiles of endoplasmic reticulum in parallel arrangement (Figs. 5 - 6); in a loss of the integrity of: the plasmalemma, the nuclear envelope and of the tonoplast. This step was also characterized by the occurrence of numerous mitochondria and by few autophagic vacuoles (Figs. 5-6) The wall loses integrity displaying its fibrillar component (Fig. 5). 


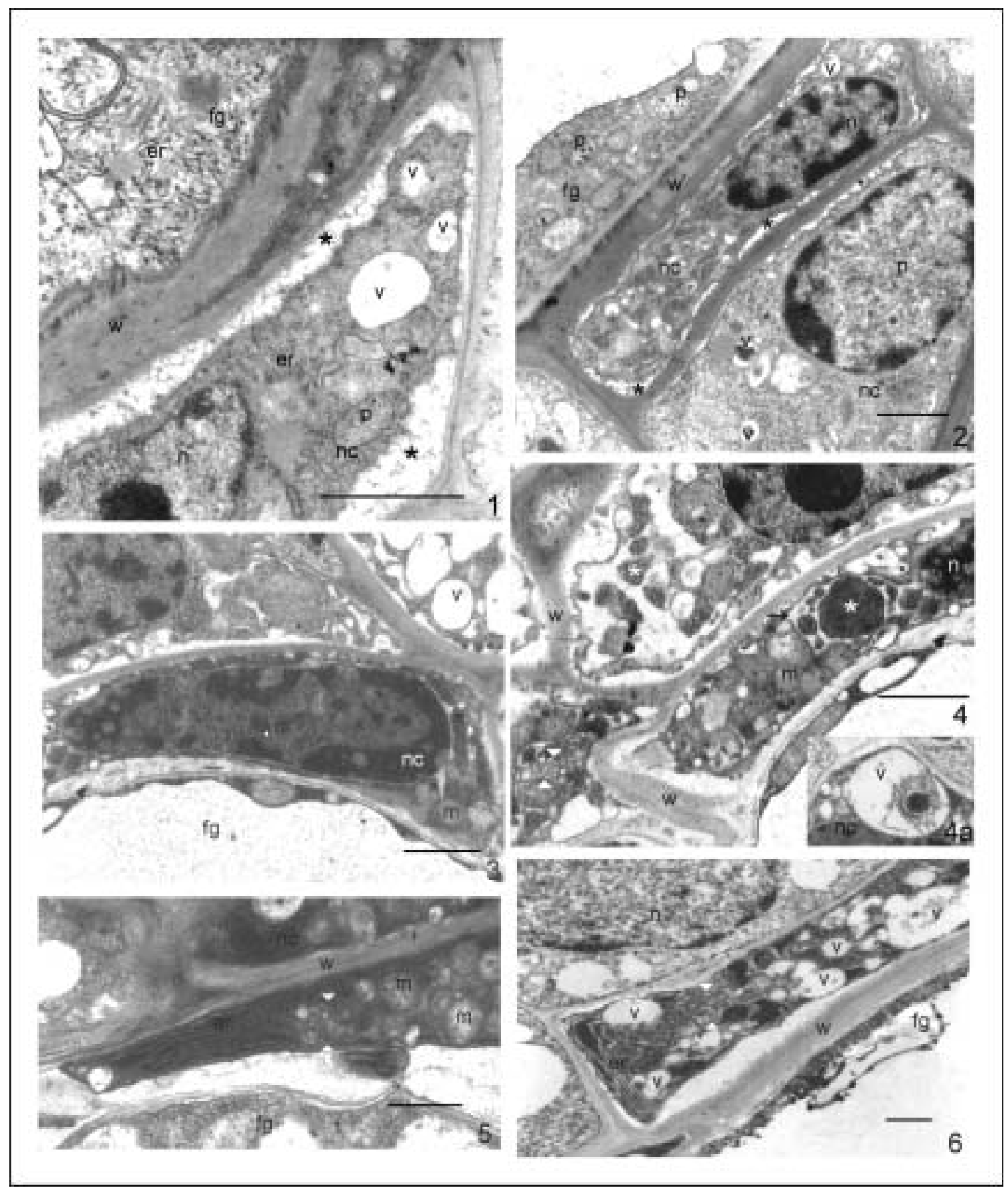

Fig. 1 - Nucellar cell showing the first signals of degeneration: the plasmalemma is detached from the wall. The resulting space between plasmalemma and cell wall is filled with droplets. Er = endoplasmic reticulum; fg $=\mathrm{female}$ gametophyte; $\mathrm{n}=$ nucleus; $\mathrm{nc}=$ nucellar cell $; \mathrm{p}=$ plastid: $\mathrm{v}=$ vacuole; $\mathrm{w}=$ wall $; *$ = extraprotoplast space. Bar $=10 \mu \mathrm{m}$. Fig. 2 - Nucellar cell near the gametophyte have changed its shape. In the more electrondense cytoplasm endoplasmic reticulum elements and phagic vacuoles containing osmiophylic material stand out. Bar $=10 \mu \mathrm{m}$.

Fig. 3 - The big nucleus of the nucellar cell show condensed chromatine. The perinuclear envelope enlarges in some points (arrowed). $\mathrm{m}=$ mitochondrion. Bar $=10 \mu \mathrm{m}$.

Fig. 4 - In the nucellar cells the endoplasmic reticulum elements subdivide the cytoplasm into bodies $(*)$ of different shape and dimensions. Many mitochondria are present. Bar $=10 \mu \mathrm{m}$.

Fig. 4a. - A deformed organelle has been engulfed by an autophagic vacuole. Bar $=10 \mu \mathrm{m}$.

Fig.s 5-6 - In the crushed protoplast of the nucellar cells, long E.R. profiles, mitochondria, autophagic vacuoles and gathered vesicles (arrowed) persist. Bar $=10 \mu \mathrm{m}$. 
Finally, the whole protoplast collapsed, thus displaying empty areas and very osmiophylic portions in which only the picnotic nucleus and 'ghosts' of the mitochondria still remained visible (Fig. 7). The concourse of vesicles also remained (Fig. 7). The cell shape was totally crushed (Figs. 8-10).

Histochemical assay - The nuclei of the nucellar cells around the female gametophyte, mainly at the chalazal pole, showed a strong fluorescence, resulting in a positive TUNEL staining (Fig. 9).

\section{DISCUSSION}

In this report we examined the manner of cell death in the nucellus of Tillandsia spp and the role of cell death in female gametophyte growth.

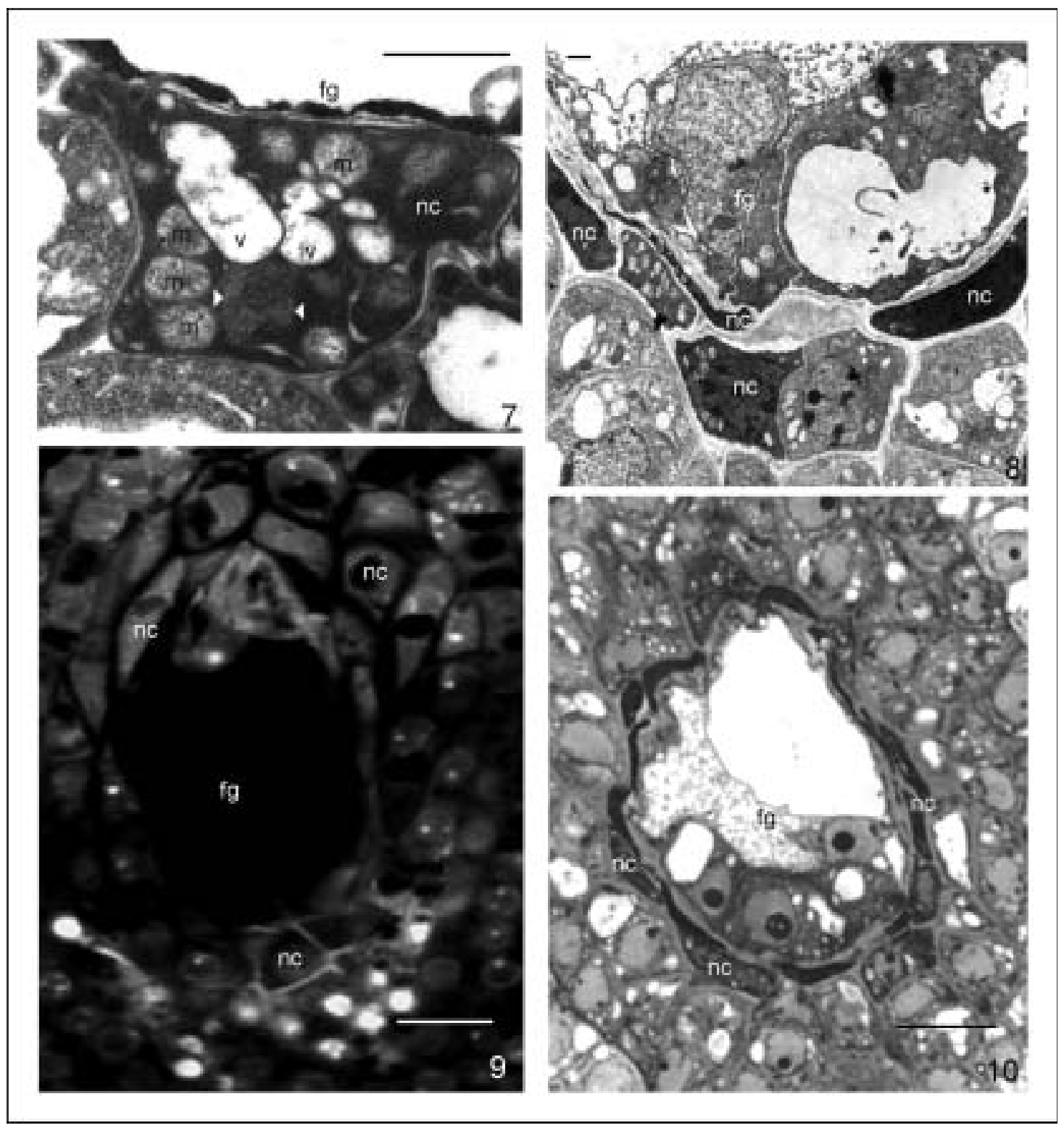

Fig. 7 - Nucellar cell at the final stages of degeneration. Only vesicles (arrowed), mitochondria and vacuoles are still recognizable. Bar $=10 \mu \mathrm{m}$.

Fig. 8 - Partial view of the female gametophyte surrounded by degenerated nucellar cells. Bar $=10 \mu \mathrm{m}$.

Fig. 9 - Programmed cell death in nucellus: in situ detection of DNA fragmentation by TUNEL procedure (yellow fluorescence of nuclei). TUNEL-positive nuclei are evident at the chalazal end. Bar $=10 \mu \mathrm{m}$.

Fig. 10 - Flower bud showing formed embryo sac stained with Toluidine blue. The nucellar cells around the gametophyte are degenerated. Bar $=100 \mu \mathrm{m}$. 
The degeneration manner - The observed ultrastructural aspects of the degeneration of the nucellar cells consisted in loss of the shape, protoplasmic shrinkage, enlargement of the perinuclear envelope, the progressive subdivision of the protoplast, appearance of autophagic vacuoles, persistence of mitochondria until the last moment of the degeneration of the cell, and wall disassembly. These morphological features are exhibited by cells which suffer a genetically determined program (DANON et al. 2000; KRISHNAMURTHY et al. 2000), even if we did not observe all the apoptotic signals listed in literature for plant cells, while the involvement of mitochondria is a typical sign of PCD linked to cytochrome c release (Rogers 2006). Besides, a peculiar feature observed in Tillandsia was the persistence of gathered vesicles. This finding is in accordance with KRISHNAMURTHY et al. (2000) who stated that in plants the PCD process can develop following diverse patterns.

As far as we know, this is the first study where the ultrastructural data of nucellar degeneration around the female gametophyte before the events of fertilization are clearly explained as programmed cell death aspects. Russell (1979) signaled in Zea mais a nucellar degeneration during the functional megaspore stage. This degeneration became more conspicuous during the twonucleate gametophyte and apparently preceded embryo sac expansion; but the process, defined by the author as autophagy associated with the gametophytic differentiation in a higher plant, was not discussed. On the other hand ultrastructural analyses have shown that in wheat grain (Triticum) the nucellus suffers a degenerative process, which starts only after fertilization (Dominguez, Moreno and Cejudo 2001). That process was citochemically and biochemically demonstrated to be programmed cell death.

In Pinus, after pollination, the growth of the pollen tube into the nucellar tissue in the direction of the female gametophyte involves the programmed death of the cells located around the pollen grain and growing tube (Hiratsuka, YAMADA and TERASAKA 2002). In contrast RUNIONS and OwEns (1999) proposed that nucellar cells of Picea are not apoptotic in that they do not spontaneously deteriorate and die before physical contact with the pollen tube.

In barley nucellar cells appeared to undergo some form of lyses rather than passive destruction by compression (NorsTog 1974). The mechanism driving nucellus autolysis in barley is unknown, but the process bore striking similarities to pro- grammed cell death in animal cells where protease plays a major role in autolysis (LINNESTAD et al. 1998). In castor bean (Ricinus communis) endosperm, the accumulation and release of an autolytic enzyme was associated with the Programmed Cell Death by SCHMID, Simpson and GIETI (1999); a specific enzyme, named nucellain, was identified by LiNNESTAD et al. (1998) in barley nucellar cell walls, but its role in autolysis was not determined. The loss of amalgam of the walls in the nucellus cell degeneration of Tillandsia may be an indicator of the involvement of the apoplast in autolysis.

The role - The presence of material in the gap between the cell membrane and the wall of the dying cells lets us assume that the protoplast remained partially isolated. Substances released with the progressive cell degeneration could be exploited by the female gametophyte. A trophyc role for the profit of the pollen grain and tube was suggested in Pinus by Hiratsuka, Yamada and Terasaka (2002) which does not exclude another possible role: to create intercellular space to ease the physical passage in the direction of the female gametophyte. In another gimnosperm, Ginkgo biloba, LI, XAN and CUI (2003) demonstrated the formation of the pollen chamber by PCD of the micropilar nucellar cells, thus attributing a physical role to PCD.

In Tillandsia, the observed ultrastructural aspects and the final shape assumed by the nucellar dying cells around the female gametophyte address our interpretation to the physical role of bringing space to the early developing gametophyte. Further in the process of seed development the nucellus is known to carry out a trophic role. In fact in the case of Triticum (Dominguez, Moreno and Cejudo 2001) the nucellar cell death in the wheat grain was reported to start after anthesis when female gametophyte is already developed. However it should be noted that no observations were made before anthesis.

The peculiar persistence of vesicles observed in the nucellar cells that undergo PCD indicated their usefulness for the finishing of the autolysis process.

Since our study was conducted on Tillandsia flowers prior to anthesis, the genetically programmed death of the nucellar cells was independent from fecundation events and embryo formation.

If early nucellar cell death is a specific feature of Tillandsia, it would be in accordance with the strategy of life and ecology of these extreme epi- 
phytes which need rapid responses either during the vegetative life or in the sexual process. We are leaded towards this interpretation considering the IV of the eight cell-categories proposed by KRISHNAMURTHY et al. (2000), the category of the hypersensitive response.

\section{REFERENCES}

Billings F. H., $1904-A$ study of Tillandsia usneoides. Botanical Gazette, 38: 99-121.

Danon A., Delorme V., Mailhac N., Gallois P., 2000 - Plant programmed cell death: A common way to die. Plant Physiology Biochemistry (Montrouge), 38: 647-655.

Davis G.L., 1966 - Systematic embryology of Angiosperms. John Wiley \& sons, INC. New York. London. Sidney.

Dominguez F., Moreno and Cejudo, 2001 - The nucellus degenerates by a process of programmed cell death during the early stages of wheat grain development. Planta, 213: 352-360.

Van Doorn W. G. and E. J. Woltering, 2005 - Many ways to exit? Cell death categories in plants. Trends in plant science, 10: 117-122.

Francini Corti E., 1981 - Epifitismo e sua evoluzione. Contributi del centro Linceo interdisciplinare di Scienze Matematiche e loro applicazioni, 57: 123184.

FRIEDMAN W.E., 1995 - The evolution of embryogeny in seed plants and the developmental origin and early history of endosperm. American Journal of Botany, 81(11): 1468-1486.

Gibbons I.R. and Grimstone, 1960 - On the flagellar structure in certain flagellate. The Journal of Biophysical and Biochemical Cytology, 7: 697-716.

Herr J.M., 1995 - The origin of the ovule. American Journal of Botany, 82(4): 547-564.

Hiratsuka R., Yamada Y. and Terasaka O., 2002 Programmed cell death of Pinus nucellus in response to pollen tube penetration. Journal of Plant Research, 115: 141-148.

Krishnamurthy K.V., Krishnaraj R., ChozhavenDAN R. and SAmuel Christopher F., 2000 - The programme of cell death in plants and animals- $A$ comparison. Current Science, 79(9): 1169-1118.

Li D. H., YANG X. and Cui M. K., 2003 - Morphological changes in nucellar cells undergoing programmed cell death (PCD) during pollen chamber formation in Ginkgo biloba. Acta Botanica Sinica, 45(1): 53-63.

Linnestad C., Doan D. P., Brown R.C., Lemmon B. E., Meyer D. J., Jung R. and Olsen O., 1998 Nucellain, a barley bomolog of the dicot vacuolar processing protease, is localized in nucellar cell walls. Plant Physiology, 118: 1196-1180.

Morrison I. N., O'Brien T. P. and Kuo J., 1978 Initial cellularization and differentiation of the aleurone cells in the ventral region of the developing wheat grain. Planta, 140: 19-30.

Norstog K., 1974 - Nucellus during early embryogeny in barley: Fine structure. Botanical Gazette, 135(2): 97-103.

Rogers H. J., 2006 - Programmed Cell Death in floral organs: how and why do flowers die?. Annals of Botany, 97: 309-315.

Runions C. J. and Owens J. N., 1999 - Sexual reproduction of interior spruce (Pinaceae). I. Pollen germination to archegonial maturation. International Journal of Plant Sciences, 160(4): 631-640.

Russel S., 1979 - Fine structure of the megagametophyte development in Zea mais. Canadian Journal of Botany, 57: 1093-1110.

Shmid M., Simpson D., and Gieti C., 1999 - Programmed cell death in castor bean endosperm is associated with the accumulation and release of a cysteine endopeptidase from ricinosomes. Proceedings of the National Academy of Science of the United States of America, 96(24):14159-14164.

Spurr A. R., 1969 - A low viscosity epoxy resin embedding medium for electron microscopy. Journal of U1trastructural Research, 26: 31-43. 
